\title{
KAJIAN HUKUM TATA NEGARA TERHADAP TIDAK OPTIMALNYA FUNGSI DPR RI SELAMA ORDE BARU
}

\author{
Muchtar Pakpahan"
}

\begin{abstract}
During Soeharto's administration which was called Orde Baru (New Orde), Indonesia had run six times general election, 1971, 1977, 1982, 1987, 1992 \& 1997. During Soeharto's administration too, authority's slogan was execution Pancasila and 1945 Constitution purely and consequently. However during New Orde, House of Representative (DPR RI) didn't optimum execute it's function. Many critics to be addressed to presiden Soeharto, but who criticized might be put in a trouble from intimidation, prison and killed. In that situation I did a research 1993 with this title. Through the research I want to inform to the people why DPRRI was not optimum and how to solve.
\end{abstract}

Keywords: House of Representative, new orde, function

\begin{abstract}
Abstrak
Selama pemerintahan Soeharto yang disebut Orde Baru (New Orde), Indonesia telah menjalankan enam kali pemilihan umum, 1971, 1977, 1982, 1987, 1992 \& 1997. Selama pemerintahan Soeharto juga, slogan otoritas adalah eksekusi Pancasila dan UUD 1945 secara murni dan konsekuen. Namun selama Orde Baru, DPR (DPR RI) tidak optimal melaksanakan fungsi itu. Banyak kritikus yang akan ditujukan kepada Presiden Soeharto, tetapi yang mengkritik mungkin dimasukkan ke dalam kesulitan dari intimidasi, penjara dan dibunuh. Dalam situasi itu saya melakukan penelitian 1993 dengan judul ini. Melalui penelitian saya ingin menginformasikan kepada masyarakat mengapa DPR RI tidak optimal dan bagaimana menyelesaikannya.
\end{abstract}

Kata kunci: DPR, orde baru, fungsi

\section{Pengantar}

Tahun 1992-1993, penulis ada melakukan penelitian "Mengapa DPR RI selama Orde Baru tidak optimal menjalankan fungsinya". Penelitian itu di maksudkan sebagai jawaban terhadap keluhan rakyat tidak/kurang berfungsinya DPR RI mengartikulasikan aspirasi rakyat.

Penelitian ini memang sudah 17 tahun yang lampau, Lalu dipublikasikan sekarang dengan maksudnya agar semua penyelenggara Negara dan para pegiat

\footnotetext{
1 Penulis adalah Staf Pengajar Fakultas Hukum UKI. Alamat kontak: muchtarpakpahan_associates@yahoo.com.
} 
politik memahami keadaan itu dan tentu agar tidak diulangi. Kata para orang bijak, sejarah/pengalaman adalah guru yang paling baik.

Selain alasan tersebut, beberapa pengamat dan pegiat Hukum Tatanegara menuntut kembali ke UUD 1945 yang asli. Mereka tidak setuju adanya 4 kali amandemen terhadap UUD 1945. Umumnya berpendapat bahwa amandemen adalah sama dengan masuknya neoliberalisme menguasai Indonesia. Padahal Sokarno berpesan ketika UUD 1945 disahkan, agar UUD yang baru segera dibentuk setelah perang Asia Timur Raya atau perang dunia II telah berakhir. Waktu reformasi, Indonesia tidak mengganti UUD 1945 melainkan mengamandemennya.

Saat ini adalah waktu yang tepat mempublikasikan penelitian tersebut dengan maksud, penulis ingin mengatakan apabila kembali ke UUD 1945 yang asli, berarti Indonesia akan kembali terperosok lagi ke masalah ketatanegaraan.

\section{Relevansi dan Tujuan Penelitian}

Relevansi penelitian ini akan terlihat dari kegunaannya. Hasil dari penelitian ini akan berguna untuk keperluan:

1. Kepentingan ilmu pengetahuan (teoritis);

2. Kepentingan praktek.

Semasa Orde Baru telah berlangsung enam kali pemilihan umum untuk menghasilkan Dewan Perwakilan Rakyat (1971, 1977, 1982, 1987, 1992 dan 1997). Anggota Dewan Perwakilan Rakyat yang dihasilkan dalam empat kali pemilihan umum itu, dihasilkan melalui pemilihan umum dengan sistem pemilihan proporsional. Selain itu tidak semua anggota Dewan Perwakilan Rakyat merupakan hasil pemilihan ${ }^{2}$. Yang tidak melalui pemilihan umum adalah anggota DPR dari ABRI, yang merupakan perwujudan dwifungsi ABRI. Tetapi selama empat kali susunan Dewan Perwakilan Rakyat sebagai hasil pemilihan umum itu, senantiasa muncul keluhan dari rakyat yang menyatakan lembaga tersebut tidak menjalankan tugasnya sebagaimana mestinya.

Keluhan rakyat muncul, padahal justru slogan orde baru adalah melaksanakan Pancasila dan UUD 1945 secara murni dan konsekwen dengan label demokrasi Pancasila. Pada kenyataannya tidak beda dengan demokrasi terpimpin ${ }^{3}$ yang digantikannya.

Diharapkan tulisan ini dapat memberikan konsep bagaimana mengoptimumkan pelaksanaan tugas Dewan Perwakilan Rakyat. Sedangkan tujuan penelitian ini adalah:

${ }^{2}$ Muchtar Pakpahan, "DPR Semasa Orde Baru”, (Jakarta: PT. BIS, 2008), dibahas disemua Bab.

${ }^{3}$ H.A. Notosoetardjo, "Proses Kembali Kepada Djiwa Proklamasi 1945", (Jakarta: Endang, 1964), hal. 335-338. 
1. Menjelaskan apa tugas DPR dan apa hak-hak DPR dan anggota dalam rangka menjalankan tugas yang diberikan UUD 1945 berserta berbagai undangundang/peraturan pelaksana lainnya.

2. Menjelaskan bagaimana DPR dan anggota masa kerja 1982-1987 melaksanakan hak-haknya dalam rangka melaksanakan tugas.

3. Mengungkapkan apakah benar anggota DPR belum optimum melaksanakan tugasnya, dan kalau benar apa penyebabnya?

4. Mencari konsep teoritis untuk mengetahui bagaimana memfungsikan anggota DPR agar dapat secara optimum melaksanakan tugasnya.

\section{Metode dan Pelaksanaan Penelitian}

Data yang diperoleh dalam rangka mencapai tujuan penelitian ini adalah data kualitatif. Data kualitatif berisikan penjelasan dasar juridis dan dasar teoritis tugas dan hak-hak DPR dan bagaimana anggota DPR beraktivitas dalam rangka melaksanakan tugas DPR.

Data ini diperoleh melalui penelitian kepustakaan dan wawancara. Penelitian kepustakaan berkaitan dengan:

1. Segala peraturan yang berhubungan dengan tugas atau fungsi dan kewajiban DPR dan anggota.

2. Berbagai karya ilmiah dan buku yang berkenaan dengan:

a. Latar belakang, pikiran atau makna, maksud dan penafsiran berbagai peraturan yang berkaitan dengan tugas atau fungsi dan hak-hak DPR dan anggota.

b. Dasar teoritis peranan anggota DPR.

3. Berbagai artikel, makalah dan publikasi lainnya, yang mengungkapkan pelaksanaan tugas atau fungsi dan hak-hak DPR dan anggota, khususnya mass media cetak.

4. Wawancara dengan:

a. Pimpinan organisasi induk fraksi-fraksi yang ada di DPR.

b. Beberapa anggota DPR yang dianggap penting menjadi nara sumber.

5. Penelitian di dua harian kompas dan sinar harapan tentang pernyataanpernyataan para anggota DPR untuk satu tahun terbitan, yakni 1985.

6. Penelitian di tiga komisi DPR, yakni : Komisi III, Komisi IX, dan Komisi APBN tentang aktivitas para anggota untuk satu tahun persidangan, yakni 1985-1986.

Perolehan data dilakukan dengan cara eksplorasi dan wawancara.

Data yang sudah tersedia dikemukakan secara deskriptif dan analitif. Deskriptif menggambarkan atau mengemukakan dasar yuridis dan teoritis tentang tugas dan hak-hak dan anggota, kemudian kenyataan pelaksanaannya. Dan analitif menjelaskan secara kritis mengapa DPR/para anggota DPR melaksanakan tugas dan hak-haknya seperti itu.

Penelitian ini hampir keseluruhannya berlangsung di Jakarta, terutama di Sekretariat Jenderal DPR-RI. Pelaksanaan penelitian ini memakan waktu satu tahun enam bulan dengan perincian: enam bulan penelitian kepustakaan (termasuk 
kepustakaan DPR), enam bulan di DPR RI, dua bulan di harian kompas, dua bulan di harian suara pembaharuan dan dua bulan wawancara. Selain itu ditambah dengan penelitian mandiri (pribadi) tentang pelaksanaan pemilihan umum $1982 \mathrm{di}$ Sumatera Utara, yang hasilnya sangat membantu laporan ini.

Selanjutnya pelaksanaan penelitian terbagi ke dalam kesatuan penelitian dan operasionalisasi.

\section{Kesatuan Penelitian}

Yang menjadi objek penelitian adalah DPR semasa orde baru dengan sampel para anggota masa kerja 1982-1987, dengan segala ketentuan yang mengaturnya. Pembatasan objek ini perlu untuk menghindari bias. Selain dimaksudkan menghindari bias yang menjadi alasan memilih DPR masa kerja 1982-1987 adalah:

a. Pada dasarnya sistem yang mendasari DPR selama Orde Baru adalah sama, sebagaimana diatur dalam UU No. 15 tahun 1969 dengan segala Undang-undang yang mengubahnya dan UU No. 16 tahun 1969 dengan segala undang-undang yang mengubahnya. Untuk mengadakan pembatasan dipilihnya satu masa kerja dari antaranya yang paling akhir dan telah mengakhiri masa kerjanya yakni 1982-1987, sebab ketika penelitian berlangsung, DPR masa kerja 1987-1992 belum mengakhiri masa kerjanya.

b. Selain butir a, hal lain yang menarik adalah anggota DPR masa kerja 1982-1987 ini sama sekali tidak ada yang pernah mencoba berusaha menggunakan haknya. Inilah yang hendak diteliti apa penyebabnya.

\section{Operasionalisasi Penelitian}

Setiap pimpinan induk organisasi fraksi yang mempersiapkan anggota DPR masa kerja 1982-1987 dijadikan responden, kecuali Panglima ABRI tidak berhasil diwawancarai. Dalam DPR ada empat fraksi: Fraksi ABRI, Fraksi Karya Pembagunan, Fraksi PPP dan Fraksi PDI. Selain itu diwawancarai juga beberapa orang anggota DPR, dua orang FKP, satu orang dari FABRI, satu orang dari PPP dan satu orang dari FDI. Pemilihan sampel adalah purposive sampling, memilih orang yang relatif lebih menonjol di fraksinya. Dari FKP ditetapkan dua orang sebagai responden karena fraksi ini mempunyai anggota dalam jumlah yang sangat besar. Kepada pimpinan induk organisasi setiap fraksi juga diajukan beberapa pertanyaan yang eksploratif.

Selain pertanyaan-pertanyaan yang diajukan kepada empat pimpinan induk organisasi tersebut juga diteliti dua massmedia: Sinar Harapan dan Kompas terbitan satu tahun, mulai 1 Januari 1985 sampai dengan 31 persen anggpta DPR yang menjalankan aktivitasnya lewat mass media (Sinar Harapan dan Kompas) selama satu tahun. Untuk memperoleh data ini penelitian dilakukan di dua harian yakni harian kompas dan sinar harapan/suara pembaruan. Selain melihat persentase, juga akan diuji mutu pembicaraan, serta kontekstualnya. Terhadap angka persentase yang tidak pernah bicara sama sekali akan dicari keterangan 
mengapa demikian. Dari data tersebut dapat pula diketahui anggota Dewan mana yang paling banyak bicara dan yang berbobot pembicaraannya.

Kemudian dilakukan pula penelitian di komisi III, Komisi APBN dan Komisi IX. Yang diteliti adalah keaktifan anggota-anggota, kehadiran, dan aktivitas mereka dalam persidangan. Ketiga komisi ini terpilih secara acak; Komisi III mewakili bidang politik keamanan (Komisi I, II, dan III), Komisi APBN mewakili bidang ekonomi, keuangan dan industri (IV, V, VI dan APBN) sedangkan Komisi IX mewakili bidang kesra (Komisi VIII, OX, X). Sebenarnya ada keinginan hendak meneliti semua komisi. Akan tetapi memilih tiga diantaranya sebagai perwakilan dapat dipertanggung jawabkan secara ilmiah. Penetapan ini juga didasari asumsi bahwa kondisi di semua komisi adalah sama.

\section{Demokrasi dan Perwakilan}

Setelah Perang Dunia Ke II banyak bangsa yang memproklamasikan kemerdekaannya terutama di Asia dan Afrika. Kesempatan untuk memproklamasikan kemerdekaan itu diperoleh oleh bangsa-bangsa tersebut setelah berakhirnya perang dunia ke II. Pada umumnya bangsa-bangsa yang melakukan penjajahan itu adalah bangsa- bangsa/negara-negara yang berada di kawasan Eropa Barat. Bangsa-bangsa yang memproklamasikan kemerdekaan itu umumnya mendasari pemerintahannya dengan demokrasi. ${ }^{4} \mathrm{Hal}$ ini dapat dipahami sebab demokrasi senantiasa merupakan cita-cita yang hidup. Penyebab lainnya karena negara-negara penjajah itu di tanah airnya mempraktekkan sistem pemerintahan demokrasi dan sebagaian tokoh-tokoh dari bangsa terjajah dididik di negara penjajah.

Akan tetapi negara-negara yang baru menyatakan kemerdekaan itu dalam banyak hal justru tidak mempraktekan demokrasi. Paling tidak dapat dikatakan terdapat pelanggaran-pelanggaran terhadap prinsip demokrasi. Ada tiga pelanggaran yang acap kali terjadi yakni:

1. Pembentukan pemerintahannya yang tidak berdasarkan pilihan Rakyat;

2. Pengadaan anggota lembaga perwakilan tidak melalui Pemilihan Umum; dan

3. Pelanggaran hak-hak azasi manusia dengan berbagai cara. Pada hal Justru hak-hak azasi manusia merupakan bagian terpenting dari demokrasi itu sendiri. Bahkan dalam melakukan pelanggaran terhadap hak asasi manusia itu banyak pemerintahannya dengan bertopengkan demokrasi.

Pelanggaran-pelanggaran tersebut bersumber pada penyebutan sistem demokrasi. Ini juga dapat dilihat dari pendapat Gilette Hichner dan Carol Levine: ${ }^{5}$

\footnotetext{
${ }^{4}$ Menurut Abraham Lincoln democracy is a government from the people,for the people, by the people. Sedangkan Prof. Padmo Wahjono, S.H., pada seminar makna Negara Hukum yang diselengarakan PIKI tanggal 17 Januari 1990 menyatakan, demokrasi adalah suatu pola tingkah laku yang berlaku pada suatu kelompok masyarakat dan diterima pola yang berlaku dalam masyarakat tersebut. Itu menikmati pendidikan dinegara penjajahnya.
} 
Hampir setiap Negara bagaimanapun sistem politiknya, mengklaim bahwa bentuknya adalah demokrasi, tetapi Kadang-kadang kata " demokratis" itu dikwalifisir dengan ekspresi-ekspresi seperti "basic" guided "paternal" "traditional" atau People sehingga dalam realitasnya "tyrannical" dan "authoritarian.

Praktek-praktek pelanggaran terhadap hak-hak asasi manusia itu menjadi perdebatan serta menarik perhatian PBB. Ini mendorong berlangsungnya konferensi Internasional Commission of Jurist 1965 di Bangkok yang berhasil merumuskan enam syarat agar suatu Negara dapat disebut sebagai Negara demokrasi ${ }^{6}$ yaitu:

1. Perlindungan konstitusional terhadap hak-hak asasi manusia dalam arti bahwa konstitusi selain menjamin hak-hak individu, harus menentukan pula cara prosedural untuk memperoleh perlindungan atau hak-hak yang dijamin;

2. Badan kehakiman yang bebas dan tidak memihak (independent and impartial tribunal);

3. Pemilihan umum yang bebas;

4. Kebebasan untuk menyatakan pendapat.

5. Kebebasan untuk berserikat/berorganisasi dan beroposisi.

6. Pendidikan kewarganegaraan (civil-education).

Jika mengikuti konsep yang dirumuskan konfrensi Internasional Commission of Jurist di Bangkok itu berarti salah satu ciri Negara Demokrasi adalah Negara tersebut haruslah memiliki lembaga perwakilan rakyat yang pengangkatannya berdasarkan pemilihan umum. Dalam perkembangan sejarah demokrasi, lembaga perwakilan sudah bagian dari perjalanan demokrasi itu sendiri, yang telah dimulai sejak pemerintahan Yunani.

Pengertian perwakilan di sini adalah perwakilan politik. Pengertian ini merupakan pengkhususan dari pendapat Arbi Sanit ${ }^{7}$ yang menyatakan:

Perwakilan dalam pengertian bahwa seseorang ataupun sekelompok orang yang berwenang menyatakan sikap itu atau tindakan yang baik yang diperuntukan bagi, maupun yang mengatasnamakan pihak lain.

Artinya yang menjadi fokus perhatian dalam hal perwakilan disini adalah hal-hal yang ada kaitannya dengan aspirasi politik.

Di Indonesia lembaga perwakilan rakyat diberi nama Dewan Perwakilan Rakyat atau DPR. Pengadaan DPR dimaksudkan untuk memenuhi unsur Negara demokrasi yang dimulai abad ke 19. Dalam hal ini Logemenn berpendapat unsur

5 Dell Gilette Hitchner and Carol Levine, "Comparative Government Politics", dalam Ismail Suny, "Mekanisme Demokrasi Pancasila", (Jakarta: Aksara Baru,1987,Cetakan Keenam ), hal. 9.

${ }^{6}$ Miriam Budiarjo, "Dasar-dasar Ilmu Politik”, (Jakarta: Gramedia , 1986 ), hal. 50-51.

${ }^{7}$ Arbi Sanit, "Perwakilan Politik di Indonesia", cetakan Pertama, (Jakarta: CV.Rajawali, 1985), hal. 23. 
Negara Republik Indonesia yang memenuhi legitimasi suatu Negara abad ke 19 dalam sistem pemerintahan Negara berdasarkan UUD 1945, ialah adanya Dewan Perwakilan Rakyat. ${ }^{8}$

Indonesia adalah salah satu Negara yang memproklamasikan kemerdekaannya setelah perang dunia ke II berakhir, sebagaimana diutarakan di muka tadi. ${ }^{9}$ Sebagai Negara bekas jajahan Belanda, termasuk negara yang sejak awal menyatakan dirinya sebagai negara demokrasi.

Ada dua hal pokok dasar yang harus diselesaikan terlebih dahulu oleh negara yang baru berdiri yaitu falsafah dan konstitusi. Artinya, sebelum menyelengarakan hal-hal yang berkaitan dengan kehidupan sebagai suatu negara, kedua dasar tersebut harus diselesaikan terlebih dahulu. Bagi bangsa Indonesia kedua dasar itu adalah pancasila sebagai falsafah Negara dan UUD 1945 sebagai konstitusi Negara. Dengan Pancasila dan UUD 1945 lah dibangun Negara kesatuan Republik Indonesia yang menetapkan sistem pemerintahan negara, Presiden berkedudukan sebagai kepala negara dan kepala pemerintahan.

Bangunan ketatanegaraan Indonesia atas kedua dasar tadi dapat digambarkan seperti berikut. Pada suprastuktur politik terdapat satu lembaga tertinggi negara ${ }^{10}$ yaitu Majelis Permusyawaratan Rakyat (MPR), dan lima lembaga tinggi Negara: Dewan Perwakilan Rakyat (DPR), Presiden yang dibantu wakil Presiden dan Menteri-Menteri, Dewan Pertimbangan Agung (DPA), Mahkamah Agung (MA), dan Badan Pemeriksa Keuangan (BPK). Secara formal konstitusional, kehidupan kenegaraan Republik Indonesia sebagai Negara yang mempunyai falsafah Pancasila dan UUD 1945, berada ditangan lembaga-lembaga Negara tersebut.

Jika dihubungkan ajaran Trias Politika dengan sistem ketatanegaraan menurut UUD 1945, badan kekuasaan DPR adalah Legislatif, Presiden (wakil Presiden dan menteri-menteri) adalah eksekutif dan MA adalah Yudikatif. ${ }^{11}$ Presidenlah yang menjalankan kekuasaan Pemerintahan negara.dalam penelitian

8 Hamid S. A. Attamimi, Peranan Keputusan Presiden Republik Indonesia dalam Penyelenggaraan Pemerintahan Negara, (sebuah Desertasi) yang dipertahankan tanggal 2 Desember 1990, di UI Jakarta, hal. 109.

${ }^{9}$ Kendatipun sebuah kemerdekaan telah beratus tahun menjadi cita-cita politik rakyat Indonesia,tetapi persiapan untuk menghadapi hari " $\mathrm{H}$ " Proklamasi tidak pernah diperkirakan kapan akan terlaksana. Itu pula yang terjadi dengan hari proklamasi tanggal 17 Agustus 1945, yang ditandai dengan belum lengkapnya perlengkapan-perlengkapan ketatanegaraan sebagai bangsa/ Negara, tetapi karena sudah didorong tekad yang dan semangat; Negara Proklamasi itu selamat hingga sekarang.

${ }^{10}$ Pengunaan istilah lembaga tertinggi Negara dan lembaga tinggi Negara adalah mengikuti tap. No. II/MPR/1973. Menurut hemat Penulis yang lebih tinggi adalah lembaga Negara tertinggi dan lembaga Negara tinggi. Sebab menurut tata bahasa mula-mula adalah kata benda mengikuti hukum MD lembaga Negara, diikuti kata sifat tertinggi atau tinggi.

${ }^{11}$ Disebut bila menghubungkan ........., karena sistem pemerintahan Negara Indonesia tidak mengikuti ajaran Trias Politica. Namun dalam pengembangannya dapat dipastikan ada pengaruhnya. 
ini akan diteliti pula hubungan yang saling terkait antara MPR, DPR dengan Presiden. Tidak berarti tidak ada kaitannya dengan tiga lembaga Negara tinggi lainnya.

Kekuasaan tertinggi Negara berada di tangan rakyat, dan dilakukan sepenuhnya oleh Majelis Permussyawaratan Rakyat (Pasal 1 ayat 2 UUD 1945) Majelis Permusyawaratan Rakyat terdiri atas anggota-anggota Dewan Perwakilan Rakyat ditambah dengan utusan-utusan dari daerah-daerah dan golongangolongan menurut aturan yang ditetapkan dengan Undang-undang (Pasal 2 ayat (1) UUD 1945). Kemudian Majelis Permusyawaratan Rakyat mempunyai tugas konstitusional yaitu menetapkan garis-garis besar haluan Negara (Pasal 4 UUD 1945), Serta memilih Presiden dan Wakil Presiden (Pasal 6 ayat (2) UUD 1945).

Anggota utama MPR adalah DPR. ${ }^{12}$ Bersamaan dengan pendapat tersebut, Soehardjo" mengatakan "anggota DPR lah sebenarnya yang menjadi inti anggota MPR" beberapa pasal UUD 1945 menyinggung DPR. Pasal 5 (1) dal Pasal 20 mengatakan "tiap undang-undang yang dibuat Presiden harus mendapat persetujuan DPR" pasal 21 memberi hak inisiatif kepada anggota DPR. Pasal 19 mengatur keanggotaan DPR. Pasal 22 berbunyi "peraturan pemerintah penganti undang-undang harus mendapat persetujuan DPR. Pasal 23 mengatur keikutsertaan DPR menetapkan APBN"

Kalau diikuti secara seksama pasal-pasal yang mengatur DPR di dalam UUD 1945, dapat dikatakan DPR mempunyai tugas yang sangat penting dalam kehidupan ketatanegaraan Indonesia. Tugas (sekaligus fungsi) itu secara garis besar dapat dibagi tiga: legislative function (fungsi legislatif), controlling function (fungsi pengawasan), dan budgeting function (fungsi buget atau anggaran). Ismail Suny ${ }^{14}$ membagi pengawasan (real parliamentary control) dalam tiga bentuk:

1. Control of executive;

2. Control of expenditure; dan

3. Control of taxation.

Dalam rangka menjalankan tugas (fungsi) yang dikemukakan di atas, DPR mempunyai beberapa hak. Berdasarkan tata tertib DPR masa kerja 1982-1987, DPR dan anggota DPR mempunyai hak-hak:

1. Di bidang tugas legislatif:

a. Hak amandemen;

b. Hak usul inisiatif.

2. Di bidang pengawasan:

12 Anggota DPR disebut sebagai anggota utama MPR, karena pasal 2(1) UUD 1945, menyebut, MPR terdiri atas angota-anggota DPR ditambah........... jadi anggota DPR adalah yang utama,sedangkan yang lainnya adalah penambah. Alasan lainya,anggota DPR mempunyai kewenangan khusus yakni melakukan tugas legislative dan pengawasan terhadap pelaksanaan pemerintahan yang dipimpin oleh Presiden.

${ }_{13}$ Soehardjo, SS, Kendala-kendala Menghidupkan Demokrasi di Indonesia, sebuah makalah yang diserahkan ke Majalah Ilmiah Bina Dharma, 1992, hal. 14.

14 Ismail Suny, "Mekanisme Demokrasi Pancasila", Cetakan keenam, (Jakarta: Aksara Baru, 1987), hal. 57. 
a. Hak meminta keterangan kepada Presiden;

b. Hak mengadakan penyelidikan;

c. Hak mengajukan pernyataan pendapat;

d. Hak mengajukan pertanyaan.

3. Di bidang anggaran, hak anggara.

\section{Kerangka Teoritis}

Sebelum melakukan pembahasan lebih lanjut, terlebih dahulu akan dikemukakan beberapa pengertian tetang konsep yang berkaitan dengan judul penelitian ini yaitu konsep Tugas, Hak dan Anggota Dewan Perwakilan Rakyat.

Istilah tugas dan hak dalam pembahasan ini diambil dari istilah yang digunakan peraturan tata tertib DPR berdasarkan keputusan No. 10/DPR-RI/III/ 82-83. Pasal 4 (1) peraturan tata tertib tersebut berbunyi "wewenang dan tugas DPR adalah:

a. Bersama - sama dengan Presiden membentuk Undang - Undang.

b. Bersama - sama dengan Presiden menetapkan anggaran pendapatan dan belanja negara.

c. Melakukan Pengawasan atas:

1. Pelaksanaan undang - undang;

2. Pelaksanaan anggaran pendapatan dan belanja negara serta pengelolaan keuangan Negara;

3. Kebijaksanaan Pemerintahan sesuai dengan jiwa Undang - Undang Dasar 1945 dan ketetapan - ketetapan Majelis Permusawaratan Rakyat Republik Indonesia.

d. Membahas untuk meratifikasi dan/atau memberikan persetujuan atas persetujuan atas pernyataan perang, pembuatan perdamaian dan perjanjian dengan negara lain yang dilakukan oleh Presiden.

e. Membahas hasil pemeriksaan atas pertanggungjawaban keuangan negara yang diberitahukan oleh Badan Pemeriksa keuangan.

f. Melaksanakan hal-hal yang ditugaskan oleh ketetapan Majelis Permusawaratan Rakyat kepada DPR.

Sedangkan mengenai hak dapat dilihat dalam pasal 8 yang berbunyi: untuk melakukan wewenang dan tugas sebagaimana dimaksud dalam pasal 4 ayat (1), DPR mempunyai:

a. Hak meminta keterangan kepada presiden.

b. Hak mengadakan penyelidikan.

c. Hak mengadakan perubahan atas rancangan Undang-Undang.

d. Hak mengajukan pernyataan pendapat.

e. Hak mengajukan/menganjurkan seseorang jika ditentukan oleh suatu peraturan perundang-undangan.

f. Hak mengajukan rancangan undang-undang, usul inisiatif.

Kemudian Pasal 9 (1) berbunyi: selain hak-hak DPR sebagaimana dimaksud dalam pasal 8, anggota mempunyai: 


\section{a. Hak mengajukan pertanyaan; \\ b. Hak protokol dan hak keuangan/administratif.}

Apabila dirangkaikan, UUD 1945 memberikan tugas yang sangat penting kepada DPR yang dipertegas lagi dalam pasal 4 (1) peraturan tata tertib. Dalam rangka melaksanakan wewenang dan tugasnya, DPR mempunyai beberapa hak. Pada akhirnya pelaksanaan hak - hak tersebut (sebagai lembaga) tergantung pada aktivitas anggota. Artinya aktivitas anggotalah yang menentukan pelaksanaan hak-hak tersebut.

Mengenai keanggotaan DPR tercantum dalam pasal 19 (1) UUD 1945 yang berbunyi: "susunan anggota DPR ditetapkan dengan UU". Selanjutnya diatur dalam UU No.16 tahun 1969 yang telah diubah dengan UU No.2 tahun 1985. Berdasarkan UU No.16 tahun 1969, anggota DPR berjumlah 460 orang, yang bersumber dari 360 orang melalui pemilihan umum dan 100 orang diangkat dari golongan karya ABRI dan bukan ABRI. Jumlah berlaku pada pemilihan umum pada tahun 1971, 1977, dan 1982. Sedangkan berdasarkan UU No.2 tahun 1985 jumlah anggota DPR adalah 500 orang, bersumber dari 400 melalui pemilihan umum dan 100 diangkat dari ABRI. ${ }^{15}$

DPR sebagai lembaga tinggi Negara mempunyai anggota 460 orang (untuk masa kerja 1982-1987). DPR menjalankan tugas dan fungsinya adalah melalui anggotanya yang 460 orang itu beraktivitas melaksanakan hak-haknya dalam rangka melaksanakan tugas atau fungsi DPR sebagai lembaga.

Pembahasan megenai Dewan Perwakilan Rakyat ini dilakukan dari sudut pandangan hukum tata Negara. Yang saling berkaitan dengan disiplin ilmu politik. Adalah kenyataan, kedua ilmu ini salling berkaitan dan saling mengisi. Dalam hal ini secara sederhana Barents ${ }^{16}$ mengambarkan bahwa hukum tata negara (lanjutan ilmu negara, pen) melakukan penyelidikan tentang rangka sedangkan ilmu politik menyelidiki daging yang membalutnya. Selain itu ditemukan juga kenyataan yang memperkuat eratnya hubungan hukum tata negara dengan ilmu politik di negaranegara lain. Di Prancis tradisi penyelidikan ilmu Politik kebanyakan berpangkal pada yuridis Konstitusional, di Inggris berdasarkan sejarah, dan di Amerika berdasarkan sosiologi. ${ }^{17}$ Pembahasan berikut adalah jawaban terhadap pertanyaan: "apa yang dimaksud dengan hukum tata negara dan apa ruang lingkupnya?"

Istilah Hukum Tata Negara merupakan terjemahan dari "staatsrecht" (bahasa Belanda). ${ }^{18}$ Ini berkaitan dengan pemikiran yang berkembang di kalangan

${ }^{15}$ Tentang sumber keanggotaan DPR akan menjadi salah satu topik pembahasan penting pada disertasi ini, karena diasumsikan salah satu penyebab lemahnya DPR bersumber dari sumber keanggotaan.

${ }^{16}$ J. Barents, "Pengantar Ilmu Politik", cetakan ketiga, (Jakarta;Erlangga,1983), hal. 77.

${ }^{17}$ Ibid., hal. $54-55$.

${ }^{18}$ Adalah penting mengemukakan terjemahan tersebut, karena membicarakan ilmu hukum tidak bisa lepas dari keadaan di Belanda. Tidak hanya karena hukum positif Indonesia banyak berasal dari Belanda, akan tetapi beberapa bilang teori hukum Indonesia seperti hukum pidana, hukum tata Negara, hukum perdata berasal dari Belanda juga. 
sarjana hukum Belanda, bahwa hukum tata negara mempunyai pengertian yang luas dan sempit. Hukum tata Negara dalam arti yang luas (staatrecht in ruime zin) dibagi atas:

1. Hukum tata Negara dalam arti sempit (staansrecht in enge zin) juga dinamakan hukum tata Negara (staatsrecht).

2. Hukum tata Negara atau hukum administrasi Negara (administratief recht).

Bila dirujuk kepada dua pengertian itu, yang dipergunakan dalam pembahasan ini adalah hukum tata Negara dalam arti sempit atau hukum tata Negara (staatsrecht).

Kleintjes dalam bukunya Staatsintellingen van Nederlands Indie halaman 1 mengatakan bahwa hukum tata Negara Hindia Belanda terdiri dari kaidah-kaidah hukum mengenai tata (inrichting) Hindia Belanda. Kaidah-kaidah tersebut mengatur alat-alat kekuasaan Negara (de met overheidsgezag bekleede organen) yang harus menjalankan tugas pemerintahan Hindia Belanda, susunan (samenstelling), tata (inrichting), wewenang (bevoegheden), dan perhubungan kekuasaan (onderlinge machtsverhouding ) diantara alat-alat perlengkapan itu. ${ }^{19}$

Menurut Kusnardi, ${ }^{20}$ istilah lain yang dipakai untuk hukum tata Negara dalam kepustakaan Indonesia adalah hukum Negara. Dalam bukunya itu Kusnardi juga mengutip beberapa defenisi dari para sarjana, Van Vollen Hoven, Van der Pot, Logemann, Apeldoorn, Wade and Philips, Poaton, A.V. Dicey, Maurice Duverger, dan Kusumadi Pujosewoyo.

Namun pendapat Logemann (salah satu dari antara sarjana yang disebutkan di atas) agaknya mendasari pembahasan ini. ${ }^{21}$ Pengertian hukum tata Negara yang dikemukakan Logemann tampaknya lebih lengkap dari defenisi yang dikemukakan oleh sarjana lainnya. Ia mengatakan bahwa hukum tata Negara (dalam arti sempit) adalah serangkaian kaidah hukum yang mengatur. ${ }^{22}$

1. Jabatan-jabatan apakah yang terdapat dalam susunan ketatanegaraan tertentu;

2. Siapakah yang mengadakan jabatan-jabatan itu;

3. Bagaimanakah cara melengkapinya dengan pejabat;

4. Apakah tugasnya (lingkungan pekerjaannya);

5. Apakah wewenang hukumnya;

6. Perhubungan kekuasaannya satu sama lain; dan

${ }^{19}$ Usep Ranawijaya, "Hukum Tata Negara Dasar-dasarnya", (Jakarta: Ghalia Indonesia, 1993), Hal. 12

${ }^{20}$ Moh. Kusnardi, dan Harmaily Ibrahim, "Pengantar Hukum Tata Negara Indonesia", (Jakarta: Pusat Studi Hukum Tata Negara FH-UI, 1988), hal. 22. Istilah hukum negara sama objeknya dengan hukum tata Negara dalam arti luas menurut pemahaman di Belanda.

${ }^{21}$ Pandangan Legemann ini, juga dibahas dalam Usep Ranawijaya, Op. Cit., hal. 13-14 dan Sri Soemantri, prosedur, hal. 144

${ }^{22}$ Sri Soemantri M., "Prosedur dan Sistem Perubahan Konstitusi", (Bandung: Alumni, 1987), hal. 144. 
7. Dalam batas-batas apakah organisasi negara (dan bagian-bagiannya) menjalankan tugas kewajibannya.

Sri Soemantri menyamakan istilah jabatan-jabatan itu dengan lembaga Negara. $^{23}$

Kelembagaan Negara untuk tingkat nasional yang diatur UUD 1945 adalah satu lembaga tertinggi Negara yakni MPR dan lima lembaga tinggi Negara yakni DPR, DPA, MA, Presiden dibantu oleh wakil Presiden dan menteri-menteri, dan BPK (yang secara sepintas telah dibahas dalam latar belakang). Satu dari antara lembaga tinggi Negara itu yaitu DPR dan anggotanya menjadi objek pembahasan dalam penelitian disertasi ini. Apabila dihadapkan dengan uraian Logemann, maka pokok pembahasannya adalah butir 4, 5 dan 7 (tugas, wewenang dan batasbatas tugas dan kewajibannya) yang dihubungkan dengan butir 2, 3 dan 6 (siapakah yang mengadakan anggota DPR dan apa hubungannya dengan lembaga negara lainnya, khususnya Presiden).

Sekali lagi ditambahkan bahwa kerangka teoritis pembahasan penelitian ini adalah ilmu hukum tata Negara. Menurut Burkens, objek penyelidikan ilmu hukum tata Negara adalah sistem pengambilan keputusan yang terdapat dalam Negara. Hal itu distrukturkan oleh hukum. ${ }^{24}$ Kemudian yang dimaksud dengan hukum positif: tertulis, tidak tertulis dan yurisprudensi. ${ }^{25}$ Selanjutnya Belifante tidak membatasi diri hanya penyelidikan hukum positif, tetapi yang tidak diatur oleh hukum positif pun dipelajari. ${ }^{26}$

Kemudian sumber hukum tata Negara menurut Usep Ranawijaya dikutip selengkapnya seperti berikut: ${ }^{27}$

Perkataan sumber hukum sebenarnya mempunyai dua arti. Arti pertama adalah sumber sebagai penyebab adanya hukum orangorang yang melakukan peranan menentukan tentang apa yang harus jadi hukum didalam Negara, Sumber dalam arti demikian di dalam bahasa Belanda dikenal dengan nama "welbron".

Buat kita kuranglah pentingnya untuk menyelidiki sumber hukum dalam arti demikian bagi hukum tata Negara Indonesia. Lebih pada tempatnya untuk diselidiki oleh ilmu politik atau ilmu sosiologi hukum. Yang perlu diketahui dan diselidiki oleh kita adalah yang mempelajari hukum tata Negara yang berlaku di Indonesia adalah sumber hukum dalam arti kedua, yaitu sumber hukum dalam arti

${ }^{23}$ Ibid., Catatan kaki. Dalam hal ini penulis sependapat dengan Sri Soemantri dalam rangka mplementasi definisi hokum tata Negara ke UUD 1945.

${ }^{24}$ Staats-enbestuasrecht Series 9, "Object en Methode Van de Staatsrechets Wetenschap", (Nijmegen: 1982), hal. Voon word.

${ }^{25}$ Ibid.

${ }^{26}$ Ibid., hal. 1.

${ }^{27}$ Usep Ranawijaya, Op. Cit., hal. 21-22. 
bentuk periumusan dari kaedah-kaedah hukum tata Negara yang terdapat dari masyarakat dari mana kita mengetahui apa yang menjadi hukum itu. Sumber hukum dalam arti bentuk perumusan ini atau dalam perkataan lain dalam arti formal, dikenal dalam bahasa Belanda dengan nama "kenbron". Sumber Hukum Tata Negara Indonesia dalam arti kedua ini sesuai dengan teori umum, terdiri atas hal-hal seperti di bawah ini:

1. Hukum tertulis, yaitu hukum hasil pekerjaan dalam bentuk perundangundangan dari berbagai badan yang berwenang.

2. Hukum adat, yaitu hukum yang tumbuh dan berkembang di dalam kehidupan sehari-hari dari rakyat yang diakui berlakunya oleh penguasa, baik yang berasal dari zaman dahulu (masa penjajahan dan sebelumnya) maupun yang timbul dan berkembang didalam masa kemerdekaan.

Pembagian Usep Ranawijaya ini dalam teori yang umum dikenal adalah hukum tertulis (butir I, pen). Jadi bila dikonstruksikan ketiga pendapat tersebut maka objek penelitian ilmu hukum tata Negara dalam penelitian ini adalah menyangkut sistem pengambilan keputusan DPR dalam rangka melaksanakan tugasnya, baik yang diatur dalam hukum (tertulis) maupun tidak tertulis. Hukum tertulis sumbernya adalah UUD 1945, tap-tap MPR, Undang-undang dan Tata Tertib DPR. Sedangkan yang tidak dalam hukum adalah kebiasaan-kebiasaan, sistem nilai dan budaya politik.

Bila diamati Batang Tubuh UUD 1945, secara keseluruhan memuat sistem pemerintahan Negara Indonesia (dalam arti luas) dan memuat aturan yang mengatur bagaimana pemerintahan tersebut dijalankan. Hal ini cocok dengan pendapat Wheare yang dikutip berikut ini. ${ }^{28}$

The word constitution is commonly used in at least two senses in any ordinary discussion of political affairs. First of all it is used to describe the whole system of government of a country, the collections of rules which estabilish and regulate or govern the government.

Rangkaian pembahasan konsep yang menjadi kerangka teoritis tulisan ini adalah sistem ketatanegaraan Indonesia, DPR mempunyai tugas atau fungsi konstitusional yaitu legislative - function, control-function, dan budgetingfunction.

\section{Hasil Penelitian} penelitian:

Berikut ini akan dikemukakan beberapa temuan penting sebagai hasil

\section{DPR- GR Melahirkan Orde Baru}

28 K.C. Wheare, "Modern Constitutions", (New York-Toronto-Melbourne: Oxford University Press, 1966), hal. 1. 
Selama ini yang menjadi pemahaman masyarakat, ialah bahwa lahirnya Orde Baru adalah tanggal 11 Maret 1966 bersamaan dengan keluarnya Surat Perintah Sebelas Maret (Supersemar). Langkah penting sebagai kelanjutan Supersemar ialah dibubarkannya PKI, dan dinyatakan sebagai partai terlarang. Bahan-bahan penataran P4 yang telah baku pun menyatakan tanggal 11 Maret 1966 sebagai lahirnya Orde Baru

Dari penelitian ini diperoleh temuan lain, dan arena temuan itu, penulis berpendapat lain. Temuan dan pendapat itu adalah seperti berikut ini. Setelah peristiwa penghianatan G30 S/PKI, Ketua DPRGR Arudji Kartawinata mengeluarkan Surat Keputusan Pimpinan DPR-GR No. 10/Pimp./1/65-66, yang membekukan 55 (lima puluh lima) anggota DPR yang berasal dari PKI dan ormas-ormasnya ${ }^{29}$ kemudian disusul lagi membekukan 8 (delapan) orang lagi. ${ }^{30}$

Kemudian tanggal 15 Nopember 1965, DPR-GR (minus keanggotaan dari PKI) mengadakan sidang paripurna. Dalam sidang paripurna tersebut, DPR-GR mengeluarkan sikap. Sikap DPR-GR dapat dilihat dari tiga butir konsideransi:

1. Bahwa apa yang disebut "Gerakan 30 September" yang berdasarkan fakta-fakta yang hingga kini diperoleh, nyata-nyata didalangi oleh Partai Komunis Indonesia (PKI) dan ormasormasnya;

2. Bahwa petualangan apa yang disebut "Gerakan 30 September" atau "Gestapu" itu adalah gerakan kontra revolusioner, karena menghianati revolusi Indonesia dan Pancasila serta melakukan tindakan-tindakan biadab di luar perikemanusiaan sehingga menimbulkan banyak korban, balik dikalangan pimpinan Angkatan Bersentaja, maupun di kalangan rakyat.

3. Bahwa rakyat pada umumnya termasuk buruh, tani, pegawai, baik yang bergabung dalam partai-partai politik serta ormas-ormas yang progresif revolusioner maupun dalam Angkatan Bersenjata

${ }^{29}$ Nama-nama yang keanggotaannya dibekuan: 1. Drs. J. Piry; 2. Nungtjik A.R; 3. R. PR. Situmeang; 4. Ny. Sundari Abdulrachman; 5. Sudojo; 6. M.H. Lukman; 7. Hanafi; 8. Sudjito; 9. Suratno; 10. Suhaemi Rachman; 11. Ir. Taher Thayeb; 12. Oey Hay Djoen; 13. Ny. Ch. Salawati; 14. Ny. Suharti Suwarto; 15. Djokosudjono; 16. Abdullah Baraba; 17. Sukatno; 18. Zaikadir; 19. Anwar Kadir; 20. Njoto; 21.0 Soedisman; 22.0 Djadi Wiroebroto; 23. Siswojo; 24. Jusuf Adjitorop, SH; 25. Tjugito; 26. E.A. Martalogawa; 27. Ny. Mudikdio; 28. Peris Pardede; 29. Wikana; 30. Djamhari; 31. Hartojo Prawirosoedarmo; 32. Abdullah; 33. S. Sardjono; 34. Trimo; 35. Pulung Djunaedi; 36. Harsono Ali Markaban; 37. Asmu; 38. Ny. Kartinah Koedi; 39. Sidik Kertapati; 40. Achmad Dasuki Siradj; 41. Hardojo; 42. Ny. Umi Sardjono; 43. Njono; 44. S. Hariowisastro; 45. F. Runturumbi; 46. Usman Muftiwidjaja; 47. Toek Subijanto; 48. Ir. Dengan Surat Keputusan No. 13/Pimp./I/1965-1966 Sakirman; 49. Ny. Tuti Nurbandijah; 50. Nn. Ting Suwarni; 51. Karel Supit; 52. Joehar Ajoeb; 53. Dr. Soeprapto, SH; 54. Ny. Fransisca; 55. Fanggiday.

${ }^{30}$ Nama-nama yang delapan orang itu adalah; 1. Susilo Prawiro Atmodjo; 2. Jagus; 3. Letkol (L) Ranu Sunardi; 4. Siauw Giok Tjhan; 5. Njak Diwan; 6. K. Wedojo; 7. Gede Poeger dan, 8. Supardi. 
mengutuk sekeras-kerasnya tindakan kontra revolusioner dari apa yang disebut "Gerakan 30 September" dan menuntut pembubaran partai-partai dan ormas-ormas yang menjadi dalang dan pelaku gestapu tersebut.

Selanjutnya sidang paripurna tanggal 15 Nopember 1965 tersebut memutuskan:

1. Mendukung sepenuhnya kebijaksanaan pimpinan Dewan Perwakilan Rakyat Gotong Royong yang telah membekukan sementara segala kegiatan anggota-anggota Dewan Perwakilan Rakyat Gotong Royong yang mewakili Partai Komunis Indonesia (PKI) dan ormas-ormasnya serta ormas-ormas lain yang tersangka terlibat ataupun melibatkan diri dalam gerakan kontra revolusioner apa yang disebut "Gerakan 30 September".

2. Mendesak kepada P.J.M Presiden/Panglima tertinggi Angkatan Bersenjata Republik Indonesia/Pemimpin Besar Revolusi Bung Karno untuk secepat-cepatnya mengambil keputusan terakhir di dalam bidang politik sesuai dengan pertanggung jawabkan beliau kepada bangsa dan Negara, terutama sekali pertanggung jawaban beliau terhadap Tuhan Yang Maha Esa, sekarang dan di hari kemudian, dan sesuai pula dengan tuntutan rakyat Indonesia melalui partai-partai politik dan ormas-ormasnya yang progresif revolusioner, yaitu supaya membubarkan Partai Komunis Indonesia (PKI) dan ormas-ormasnya.

3. Mendesak pemerintah dalam waktu yang singkat memberikan keterangan resmi di muka Sidang Dewan Perwakilan Rakyat Gotong Royong mengenai jalannya peristiwa petualangan kontra revokusioner yang disebut "Gerakan 30 September".

Dengan dibekukannya anggota DPR GR sebanyak 62 orang (sebab satu orang direhabilitir), maka jumlah anggota yang bersidang waktu itu adalah 299-62=237 anggota. Kalau dilihat dari perubahan iklim politik, secara formal kelembagaan DPR GR-lah yang pertama membersihkan dirinya dari unsur-unsur PKI dan ormas-ormasnya. Keputusan politik DPR GR dalam bentuk 'pernyataan pendapat tentang petualangan Gerakan 30 September' tersebut membawa pengaruh terhadap iklim politik yang semakin revolisoner. Implikasi yang berikut adalah memenuhi tuntutan tritura sebagai realisasi adanya peristiwa G30S/PKI, sampai pembubaran PKI beserta ormas-ormasnya. Oleh karena itu, sidang DPR GR tanggal 15 Nopember 1965 adalah titik kulminasi orde lama dan awal orde baru. ${ }^{31}$

Walaupun DPR GR yang bersidang tanggal 15 Nopember 1965 tersebut adalah hasil bentukan "demokrasi terpimpin", serta dalam suasana iklim politik Nasakom, dan tata tertibnya dibuat berdasarkan Peraturan Presiden,

${ }^{31}$ Sekretariat DPR-GR, Himpuanan Tata Tertib DPR RI. 
tetapi DPR GR berani mengambil keputusan politik yang menjalankan fungsi konstitusionalnya: ${ }^{32}$

a. Mendobrak demokrasi terpimpin; dan

b. Meniadakan Nasakom

Kalau pendekatannya adalah pendekatan negara yang berkedaulan rakyat, maka haruslah dicatat bahwa tanggal 15 Nopember 1965 itulah hari lahirnya orde baru, dan DPR GR lah yang melahirkannya.

\section{Penyebab DPR Tidak Bertugas Optimum}

Ada empat hal penyebab DPR RI semasa Ode Baru tidak optimum melaksanakan fungsinya. Ke empat hal itu adalah:

a. Sistem politik dari hukum politik (empat UU di bidang politik);

b. Peraturan Tata Tertib DPR;

c. Kesiapan anggota DPR, dan;

d. Budaya politik.

\section{Ad. a. Sistem Politik dari Hukum Politik}

Pembahasan ini terkait dengan 4 (empat) undang-undang di bidang politik, serta 3 (tiga) undang-undang pendukung. Keempat undang-undang bidang politik dimaksud adalah:

1) UU No. 16 Tahun 1969 tentang Susunan dan Kedudukan Majelis Permusyawaratan Rakyat, Dewan Perwakilan Rakyat dan Dewan Perwakilan Rakyat Daerah beserta dengan segala undang - undang yang mengubahnya;

2) UU No. 15 Tahun 1969 tentang Pemilihan Umum beserta segala undang-undang yang mengubahnya;

3) UU No. 3 Tahun 1975 tentang Partai Golkar dan Golongan Karya beserta segala undang-undang yang mengubahnya; dan

4) UU No. 8 Tahun 1975 tentang Organisasi Kemasyarakatan.

Kemudian empat undang-undang pendukung ialah:

1) UU No. 11 tahun 1986 tentang Peradilan Umum;

2) UU No. 2 tahun 1986 tentang Peradilan Umum;

3) UU No. 8 Tahun 1974 tentang Pokok - pokok kepegawaian;

4) UU No. 5 Tahun 1974 tentang Pokok - pokok Pemerintahan di Daerah.

Kedelapan undang-undang tersebut menghasilkan sistem politik yang terwujud dalam:

1) Mekanisme aspirasi politik;

2) Kedudukan ABRI, Pegawai Negeri dan Pegawai lainnya.

\footnotetext{
${ }^{32}$ Ibid., hal. 240.
} 
Kedua hal ini akan dibahas dalam rangka mencari penyebab kurang berfungsinya anggota DPR khususnya melaksanakan pengawasan yang bersumber dari berbagai undang-undang. Selanjutnya akan diuji pelaksanaan dari ketujuh undang-undang tersebut.

\section{Mekanisme Aspirasi Politik}

Pembahasan ini dimulai dengan memperlihatkan mekanisme aspirasi politik seperti bagan berikut ini:

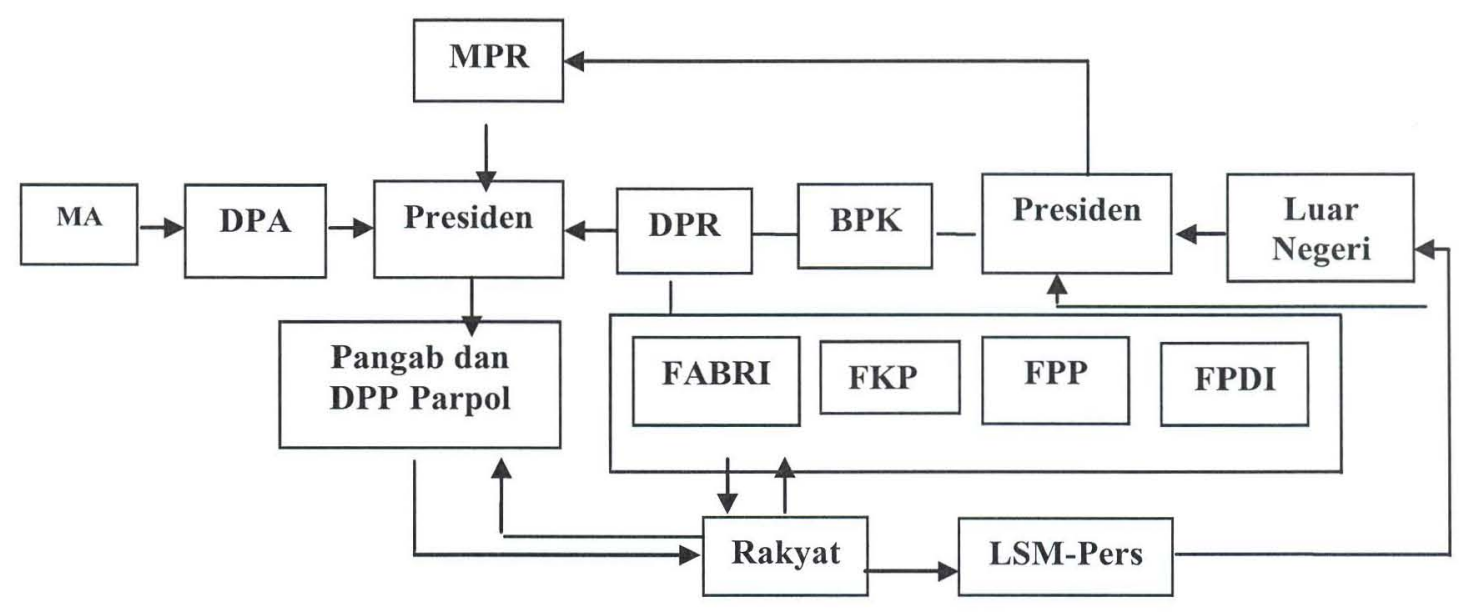

Pada tingkat suprastruktur politik terdapat satu lembaga tertinggi Negara (MPR), dan empat lembaga tinggi Negara (Presiden, DPR, MA, dan BPK).

Eksistensi pejabat dari suprastruktur politik ditentukan oleh infrastruktur politik. Kehidupan dan ruang gerak infrastruktur politik ditentukan oleh suprastruktur politik. Sebagai Negara yang berdasarkan hukum (rechstaat), suprastruktur politik menetapkan berbagai ketentuan yang mengatur bagaimana infrastruktur melakukan kegiatan. Atas dasar ketentuan itulah suprastruktur menangani kehidupan infrastruktur.

Presiden adalah central authority dari suprastruktur. Presiden adalah Kepala Negara atau administrator tertinggi dalam negara, dan juga Kepala Pemerintahan atau pemimpin atau penanggungjawab Kabinet. Jadi, kedudukan presiden adalah sentral. Hal itu merupakan penjabaran presiden selaku penyelenggara tertinggi pemerintahan negara. Attamimi menyebutnya Presiden selaku penyelenggara tertinggi pemerintahan negara. Dan bila ditinjau dari cita negara kesatuan, kepala negara (Presiden) adalah titik sentral daripada persatuan negara dan rakyat. ${ }^{33}$ Infrastruktur politik berada di antara suprastruktur politik dengan substruktur atau rakyat. Fungsinya adalah penyalur dan pengartikulasi

\footnotetext{
${ }^{33}$ Hamid. S Attamimi, Op. Cit., hal. 115.
} 
aspirasi rakyat ke suprastruktur politik dan juga penyalur kebijakan suprastruktur politik ke substruktur. Kenyataannya, fungsi penyalur kebijakan suprastruktur politik ke substruktur dapat dikatakan berjalan dengan baik. Tetapi fungsi sebagai penyalur aspirasi politik dan kepentingan rakyat ke suprastruktur politik tidak berjalan dengan baik. Dapat dikatakan aspirasi dan kepentingan rakyat tidak tersalurkan dengan baik. Ketidakseimbangan fungsi terjadi karena infrastruktur politik tidak menjalankan tugasnya sebagaimana mestinya.

Berbagai kasus yang menyangkut aspirasi/kepentingan rakyat tidak tersalurkan dengan baik. Seperti kasus tanah yang menyangkut hidup rakyat banyak, yaitu penggusuran-penggusuran tanah demi proyek pembangunan. Jumlah kasus tanah untuk tahun sidang 1982-1983 ada 350 kasus, tahun sidang 1983-1984 ada 440 kasus, tahun sidang 19851986 ada 300 kasus, tahun sidang 1986-1987 ada 124 kasus tanah. ${ }^{34}$ Semua kasus tersebut adalah kasus-kasus yang berhubungan dengan kekuasaan suprastruktur politik.

Masalah pertanahan umumnya menyangkut ganti rugi. Proyek pembangunan membutuhkan tanah, untuk itu tanah rakyat baik hak milik sertifikat atau hak milik adat maupun hak menggarap dibebaskan. Sudah ada ketentuan yang mengatur tata cara pembebasan tanah baik UU No. 21 Tahun 1960 maupun Permendagri No. 15 Tahun 1975, namun di lapangan tidak berjalan sesuai dengan kedua ketentuan tersebut. Harga tanah dibawah standar/harga pasar dan musyawarah dilangsungkan oleh aparat pemriuntahan dengn cara akal-akalan. ${ }^{35}$ Bila ada rakyat yang menuntut ganti rugi lebih tinggi dari yang sudah ditentukan, akan dituduh sebagai anti pembangunan, anti orde baru, sama dengan PKI. Bila rakyat menerima cap seperti itu, rakyat pasti terpaksa menyerah karena ketakutan.Tidak hanya berhenti di situ, banyak juga rakyat pemilik tanah yang ditangkap, ditahan, dan diinterogasi serta dilanjutkan dengan wajib lapor secara periodik, ada mingguan dan ada pula harian. ${ }^{36}$ Walau kasus tanah berlangsung secara ajeg dalam tenggang waktu yang lama kelihatannya infrastruktur politik tidak berdaya. Lembaga pengawasan di suprastruktur politik yakni DPR dan Mahkamah Agung juga tidak berdaya. Bahkan terjadi rantaian kasus, yang satu belum selesai sudah muncul kasus yang lain.

${ }^{34}$ Sekretaris Jenderal DPR RI, DPR periode 1982-1987, hal 105.

${ }^{35}$ Banyak kasus tanah memperlihatkan pendekatan cara akal - akalan. Yang paling jelas lihat Muchtar Pakpahan, Menarik pelajaran dari Kedungombo (1990).

${ }^{36}$ Dari Pengalaman penulis mendampingi/membela rakyat di proyek Inalum Asahan dan Proyek Indorayon di Sumatera Utara, Gunung Balak di Lampung, dan bendungan Kedungombo di Jawa Tengah, ada orang yang dicap menjadi PKI karena mempertahankan haknya. Bahkan ada yang ditahan beberapa hari. Dalam menghadapi tindakan seperti ini stamina rakyat mempertahankan haknya pasti mengendur. 
Dengan kata lain, saluran aspirasi/kepentingan rakyat benar-benar tersumbat. Lalu muncullah fenomena baru sejak akhir decade 1970-an yaitu LSM (Lembaga Swadaya Masyarakat) yang parallel dengan istilah NGO (Non Government Organization) di negara-negara Eropa Barat. LSM dalam banyak kasus tampil menjadi media alternatif yang menyalurkan aspirasi/kepentingan rakyat. Namun dirasakan juga tanpa tekanan/suara dari luar negeri, suara dari dalam negeri (LSM) tidak cukup punya arti. Seperti di Kedung Ombo, setelah ada tekanan dari luar negeri Pemerintah menempuh kebijakan yang memperhatikan aspirasi/kepentingan rakyat yang masih bertahan.

Setelah diteliti dan dikaji, penyebab utama terhambatnya lalu lintas aspirasi/kepentingan rakyat tersebut adalah struktur dan kelembagaan politik (sistem politik) yang dihasilkan oleh empat undang-undang di bidang politik dan empat undang-undang pendukung. DPR yang anggota utama MPR itu bertugas mengawasi jalannya pemerintahan yang dipimpin oleh Presiden. DPR terdiri dari empat fraksi, FABRI, FKP, FPP dan FDI. Keputusan dan atau sikap politik dari DPR ditentukan oleh perangkat pimpinan fraksi yang tunduk kepada pimpinan induk organisasi. Pimpinan FABRI tunduk kepada Panglima ABRI. Pimpinan FKP tunduk kepada DPP Golkar yang dipimpin oleh Ketua Umum, Pimpinan FPP tunduk kepada DPP-PPP yang dipimpin oleh ketua umum, dan pimpinan FDI tunduk kepada DPP-PDI yang dipimpin oleh Ketua Umum.

Itulah satu sisi wajah dari DPR dengan induk organisasi yang menugaskan anggota DPR, sedangkan wajah lainnya adalah seperti berikut: Panglima ABRI secara otomatis adalah jajaran eksekutif (Presiden) yang tunduk dan bertanggungjawab kepada Presiden. Serta pengadaan pejabat Panglima ABRI sepenuhnya adalah di tangan Presiden. Di DPP Golkar, Presiden Soeharto adalah Ketua Pembina sedangkan DPP Golkar tunduk pada putusan Dewan Pembina. Secara juridis Presiden dapat membekukan DPP Organisasi Sosial Politik dengan alasan stabilitas. Kenyataan lain, di intern PPP terus menerus berlangsung pertikaian dari satu bentuk ke bentuk lain serta dari masalah ke masalah lain sejak fusi hingga Kongres 1990. Selama itu pula pihak-pihak yang bertikai sama-sama meminta ditengahi oleh Pemerintah. DPP-PPP tidak mandiri dalam mengambil keputusankeputusan yang strategis, termasuk menentukan personil organisasi.

PDI hampir tidak beda dengan PPP, sejak fusi hingga penulisan ini, bertikai terus. Selama 3 kali kongres (Kongres I, II dan III), pemerintah mempunyai peran yang menentukan untuk menetapkan personil DPPPDI termasuk Ketua Umumnya. Menarik juga dikemukakan pendapat Nico Daryanto, sebagai berikut: ${ }^{37}$

${ }^{37}$ Media Indonesia, Senin 27 April 1992, hal. 1. Nico Daryanto adalah Sekretaris Jenderal DPP-PDI, semenjak tahun 1986. Ia menjadi Sekretaris Jenderal PDI bukan atas pilihan Kongres III, tapi atas pilihan pemerintah c/q Menteri Dalam Negeri waktu itu Suparjo Rustam. 
Menjadi aktivis partai, Sekjen sebenarnya serba sulit. Menjadi sekjen PDI tidak bisa dilepaskan dari keberadaan pemerintah selaku Pembina Parpol/Golkar yang sedikit banyak pasti ikut menentukan orang yang berada di puncak pimpinan Orsospol. Siapa yang menjadi pimpinan telah disetel terlebih dahulu, termasuk saya. Karena itu saya pun harus menyesuaikan dengan yang menyetel.

Dalam keberlangsungan pertikaian yang sambung menyambung dalam tubuh partai, pihak-pihak yang bertikai selalu mengandalkan pejabatpejabat pemerintah. ${ }^{38}$ Dari uraian di atas dapatlah disimpulkan bahwa DPP ketiga organisasi social politik tersebut tidak mandiri mengambil keputusan politiknya. Bahkan senantiasa lebih banyak bergantung kepada pemerintah, atau lebih banyak menjadi pendukung pemerintah. Dalam hubungan ini agaknya menarik juga dikemukakan kesimpulan penelitian Hans Thoolen, bahwa demokrasi terpimpin sama dengan apa yang dipraktekkan Orde Baru. Pendapat selengkapnya dikutip. ${ }^{39}$

Under Sukarno's guide democracy, parties were controlled in the name of political lenity and nationalism; under the new order they are being treated in the some way in the name of security and national development.

Secara tersendiri kesimpulan Thoolen ini menarik dibahas. Iklim yang demikian menunjukkan bahwa DPR kurang berdaya melakukan pengawasan terhadap pemerintah. Dari risalah persidangan DPR periode ini, hampir tidak ada kritik yang tajam terhadap pemerintah. Bahkan biasanya setelah anggota DPR melakukan kritik, mereka akan cepat mengeluarkan pernyataan mendukung, atau menyatakan dapat memahami tindakan pemerintah. Bahkan ada kecenderungan perkataan "dapat memahami tindakan pemerintah" menjadi kalimat yang baku di DPR.

\section{Kedudukan ABRI, Pegawai Negeri dan Pengawasan Lainnya}

Secara khusus sistem politik telah dijelaskan di atas. ABRI mempunyai kedudukan yang khusus dan khas. Dalam rangka menggambarkan struktur kelembagaan politik ketatanegaraan Indonesia, Penulis akan memaparkan sumber suprastruktur politik. Dalam sumber tersebut, ABRI berada pada kedudukan infrastruktur politik, sama denga Golkar, PPP dan PDI. ${ }^{40}$ Tetapi bila memperhatikan panglima ABRI secara

${ }^{38}$ Sudah menjadi kebiasaan dalam praktek politik, tidak ada pemerintahan kabinet partai yang berkeinginan partai yang tidak memerintah menjadi kuat, baik organisasi atau financial maupun massa.

${ }^{39}$ Hans Thoolen, "Indonesia And The Ruleof Law", (Printer, 1987), hal. 17.

${ }^{40}$ Panglima ABRI berkedudukan sebagai Menteri Negara. 
juridis adalah anggota eksekutif, ${ }^{41}$ maka ABRI juga adalah suprastruktur politik. Jika memperhatikan pendekatan juridis dan fungsi militer pada umumnya di Negara-Negara lain, ABRI lebih tepat ditempatkan pada suprastruktur politik. Pada suprastruktur politik, ABRI berfungsi sebagai eksekutif yang mempertahankan Negara dari ancaman bahaya baik dari dalam maupun dari luar dan mempertahankan/menjaga stabilitas dan keamanan Negara.

Negara dalam pengertian abstrak (in abstracto) adalah Indonesia yang berdasarkan Pancasila dan UUD 1945. Negara dalam pengertian yang konkrit/nyata (in concreto) adalah Indonesia mempunyai wilayah terbentang dari Sabang hingga Merauke yang saat ini di bawah pemerintahan orde baru dipimpin oleh Presiden Soeharto. Fungsi mempertahankan dan mengamankan Negara dalam pengertian abstrak dan konkrit itulah terutama fungsi ABRI. Karena fungsi tersebut adalah fungsi eksekutif, sebenarnya ABRI berada pada suprastruktur politik jajaran eksekutif. Sebagai lembaga yang berfungsi mempertahankan Negara dan menjaga keamanan Negara, ABRI berhak serta wajib menginterogasi, menangkap dan menahan yang dicurigai menghancurkan Negara dan atau mengganggu keamanan Negara. Sebagai lembaga, pihak dan aparat yang melaksanakan fungsi eksekutif, ABRI seharusnya berada pada posisi yang diawasi. ABRI wajib mempertanggungjawabkan tindakannya, apalagi mempertanggung jawabkan setiap peluru yang ditembakkan baik kepada manusia atau makhluk bernyawa lainnya, maupun untuk kepentingan latihan. Sebab setiap peluru dibeli dari uang Negara atau uang rakyat.

Struktur politik yang ada sekarang berdasarkan undang-undang yang sudah dikemukakan di muka, ABRI berada pada eksekutif. Sementara itu, ABRI juga adalah anggota DPR yang berfungsi mengawasi Presiden yang notabene sebagai Panglima Tertinggi ABRI. Oleh karena itu, adalah hal yang tidak mungkin bagi FABRI melakukan tugas pengawasan, sebab anggota DPR dari ABRI tunduk kepada Pimpinan FABRI dan Pimpinan FABRI tunduk kepada Panglima ABRI. Bahkan ada kesan kehadiran ABRI melalui FABRI di DPR mematikan fungsi pengawasan DPR dari fraksi lainnya.

Terlihat dari pengalaman DPR masa kerja 1971-1977, dan 1977-1982, FABRI yang paling keras menentang FPP dan FDI ketika kedua fraksi ini mengusulkan agar DPR menggunakan hak (pengawasan) interpelasi dan angket. Yang paling nyata adalah ketika DPR fraksi PPP dan PDI meminta angket soal korupsi di Pertamina., FABRI yang paling di depan menentang. Kemudian ketika ada suara meminta agar ada angket soal peristiwa Tanjung Priok tahun 1984, FABRI yang paling di depan menyatakan tindakan pemerintah (dalam hal ini ABRI) sudah tepat. Sikap FABRI yang demikian itu di DPR sesungguhnya adalah wajar.

${ }^{41}$ Kerja sama DPRRI FH UI. Op. Cit., hal. 73. 
Hasil penelitian kerja sama DPR RI-FH UI mengemukakan: "FABRI dan FKP selalu bersikap sama dengan keinginan pemerintah". ${ }^{4}$

Untuk melihat kemandegan pengawasan lainnya, akan dikemukakan beberapa peristiwa berikut ini. Pada kampanye Pemilihan Umum tahun 1982 yang menghasilkan DPR 1982-1987, beberapa ungkapan principal dari eksekutif tidak dipertanggungjawabkan di DPR. Diantaranya dikemukakan berikut ini: Menteri Agama, Letjen TNI Alamsyah Ratu Perwiranegara sewaktu kampanye Golkar di alunalun Cililitan Bandung hari Minggu 10 April 1982 mengatakan: "Bila Golkar kalah, keadaan bakal kacau dan kemenangan Golkar bukan saja kemenangan di dunia, tapi juga kemenangan di akhirat". ${ }^{3}$ Menteri Penerangan Letjen TNI Ali Murtopo pada kampanye putaran ke empat 16 April 1982 ada mengatakan:

Hai angkatan muda Golkar bangkitlah menghadapi pengacau dan perusak. Ketahuilah ada pengacau-pengacau, ada penghianat yang merusak dan merobek merah putih, hadapi dengan tegas hadapi dengan keberanian. Di mana patriotikmu, di mana nasionalismu. ${ }^{44}$

Kemudian pada tanggal 17 April 1982, Ali Murtopo di depan keluarga Departemen Perindustrian ada mengatakan:

Lawan-lawan Golkar ialah Kelompok Petisi 50, Aliran Pembajak Teroris Imron, Kelompok Malari 1974, dan kelompok Pengacau Lapangan Banteng sewaktu kampanye Golkar 18 Maret 1982. ${ }^{4}$

Menteri Dalam Negeri, Jenderal TNI Amir Machmud di Palu ada mengatakan:

Adalah tidak benar apabila pembangunan sekarang dibiayai oleh rakyat, karena dana yang dikumpulkan dari rakyat melalui Ireda dan Ipeda hanya berjumlah satu persen dari seluruh dana pembangunan. ${ }^{4 \hat{6}}$

Terhadap kritik anggota DPR dari fraksi PDI dan PPP, beberapa hari kemudian Amir Machmud menandaskan "haram bagi saya menarik kembali ucapan-ucapan yang telah diucapkan". 47

\footnotetext{
${ }^{42}$ Ibid.

${ }^{43}$ Ibid.

${ }^{44}$ Sinar Indonesia Baru, 17 April 1982, halaman 1.

${ }^{45}$ Ibid.

${ }^{46}$ Sinar Pagi, 19 April 1982, hal. 1.
} 
Pangkoptamtib Laksamana TNI Sudomo atas pertanyaan wartawan mengemukakan:

Para Jurkam (juru kampanye, pen) tidak mendidik dalam pengertian pendidikan politik. Seperti diketahui Parpol dan Golkar itu mempunyai tugas mengadakan pendidikan politik pada masyarakat untuk menambahkan kesadaran sebagai warga Negara dan meningkatkan kesadaran, disiplin hukum serta partisipasi aktif dalam pembangunan. Tapi ini belum terlaksana. Sebagai bukti, walau sudah ada peraturanperaturan kampanye seperti tidak boleh menyebutkan mengenai pemerintah, kontestan dan persoalan agama, tapi toh akhirnya dilanggar, yang timbul hanya menghasut". 48

Apa yang dikemukakan empat pejabat pemerintahan (eksekutif) di atas, secara principal harus diuji dengan Pancasila, UUD 1945, Undangundang lainnya serta kepatutan dan kewajaran. Apakah benar bila Golkar kalah maka Negara akan kacau? Apakah pidato Ali Murtopo itu tidak membahayakan keamanan sebab menghasut? Apakah benar secara prinsip bahwa pembangunan nasional itu tidak dibiayai rakyat? Apakah benar dalam kampanye pemilihan umum tidak boleh menyebut pemerintah? Tidak satupun ada pernyataan yang mengkritik atau pun yang meluruskan dari FABRI. Pada pihak lain berlangsungnya keadaan tersebut dapat dipahami, sebab keempat Menteri tersebut di samping kedudukannya adalah anggota eksekutif, yang paling menentukan sumbernya sama-sama dari ABRI dan pangkatnya rata-rata lebih tinggi dari anggota DPR dan FABRI. Kalau demikian FABRI dalam DPR tidak mewakili rakyat, akan tetapi mewakili ABRI. ABRI secara komando berada di tangan Panglima ABRI yang tunduk kepada Panglima Tertinggi yaitu Presiden.

Apa yang dialami PPP di Aceh menarik untuk diungkapkan. Seorang anggota DPRD I Propinsi Daerah Tingkat I Aceh Drs. Tengku Jamaluddin Wali, ditahan di Tapak Tuan ibukota Aceh Selatan. Ia ditahan 1 (satu) bulan 10 hari, April-Mei 1977 atau selama masa kampanye. Masa tahanannya 5 hari di Polres, 10 hari di Kejaksaan, dan 25 hari di penjara. Ia dibebaskan setelah pemilihan umum berlangsung tanpa diadili. Alasan penahanan karena Jamaluddin dalam pidato kampanye sebelumnya mengemukakan tanda-tanda hari kiamat,

${ }^{47}$ Sinar Indonesia Baru, 21 April 1982, hal. 1. Hal itu ditandaskan sebagai reaksi terhadap kritik yang dilontarkan Sabam Sirait dan Amin Iskandar. Sabam Sirait mengatakan: "Apa yang ditegaskan oleh Amir Machmud bertentangan dengan asas dan cita - cita bahwa pemerintah dari rakyat, oleh rakyat. Pemerintah hanya memegang titipan kuasa dari rakyat, sebagai tersirat dan tersurat dalam UUD 1945. Jadi apakah retribusi, cukai, minyak bumi bukan dari rakyat?" Mengenai hal yang sama Amin Iskandar mengatakan "keberhasilan pembangunan tidak hanya satu grup, dan tidak hanya pemerintah. (The Indonesia Times, 21 April 1982). Hal yang sama diungkapkan juga pada Sinar Indonesia Baru, 23 April 1982, hal. 1.

${ }^{48}$ Sinar Pagi, 26 April 1982, hal. 1 
timbulnya perzinahan yang merajalela akan melahirkan anak haram jadah yang banyak, suatu ketika pemimpin bangsa ini bias saja anak haram jadah tersebut. Hal yang hampir sama juga dialami oleh Drs. Tengku Gazali Amna, Ketua DPW PPP Propinsi Aceh yang juga anggota DPRD I Propinsi Aceh. Oleh Kepala Kepolisian Resort Banda Aceh ia dilarang kampanye selama satu minggu, karena menyatakan, "Kalau Golkar menang, belum tentu putra daerah yang menjadi Gubernur seperti di Bengkulu".

Sebenarnya apa yang dikemukakan oleh Menteri Agama, Menteri Dalam Negeri dan Menteri Penerangan di atas lebih dari salah atau sama salahnya dengan yang dikemukakan anggota DPRD I dari FPP tersebut. Masalahnya untuk ungkapan ketiga Menteri tersebut ABRI tidak bertindak dan FABRI diam. Demikian sebaliknya, untuk ungkapan anggota DPRD I dari FPP tersebut, ABRI bertindak dan FABRI diam.

Ada lagi kerancuan yang timbil dari kehadiran FABRI di DPR. Dari daftar anggota DPR yang dilantik berdasarkan Kep.Pres. No.140 tahun 1982, 33 (tiga puluh tiga) orang dari FABRI adalah TNI Purnawairawan. Sementara itu pernah ada perwira TNI yang masih aktif menjadi pemimpin dari Golkar. Dari keadaan ini sekurangkurangnya ada dua hal yang harus dipercakapkan secara kritis, yaitu:

\section{Secara politik ABRI harus netral}

Salah satu latar belakang ABRI tidak ikut pemilihan umum adalah ABRI sebagai tulang punggung pertahanan dan keamanan serta pemegang senjata harus berada pada satu komando. ABRI harus satu, tidak boleh terpecah pecah. Bila ABRI ikut pemilihan umum dan ikut organisasi politik, maka ABRI akan terpecah pecah seperti pada zaman orde lama.sebagi individu adalah tidak adil bila ada warga Negara yang tidak ikut memilih dan karena itu tidak punya wakil. Oleh karena itu, diberikanlah jatah kursi di DPR bagi ABRI yang kemudian disebut golongan karya ABRI. Karena ABRI sudah memperoleh jatah di DPR, ABRI harus mempunyai sikap yang sama (netral) terhadap ketiga organisasi social politik. ABRI dalam menjalankan fungsinya terhadap ketiga organisasi social politik, seharusnya menempatkan diri dalam jarak yang sama. Kenyataannya, ABRI saling mengisi dengan Golkar. Pimpinan ABRI berulang-ulang menandaskan bahwa ABRI adalah milik semua golongan politik, tapi dalam kenyataan lain. Dalam hal ini misalnya dikutip tulisan Julian Boileau: ${ }^{49}$

The army chief of staff,general Yusuf (The commander of military, pen.,) has repeatly proclaimed that ABRI must be above all groups; that ABRI must stand in the middle,

49 Julian M. Boilen, "Golkar Functioned Group Politics In Indonesia", (Jakarta: CSIS, 1983), hal. 123. 
stressing that ABRI is the property of all groups in Indonesia, thus implying that ABRI's continued membership in the great Golkar family was now inappropriate. That is a growing awareness that Golkar can not depend on ABRI forever. The problem is that if ABRI did withdraw from Golkar, Golkar would be greatly weakened. ABRI is the major pillar of the Golkar organization.

\section{ABRI harus konsekuen mengenai personil}

Yang dimaksud personil ABRI adalah mereka yang aktif berdinas di empat angkatan: Angkatan Darat, Angkatan Udara, Angkatan Laut dan Kepolisian. Apabila seseorang sudah purnawirawan, ia akan menjadi rakyat biasa. Dapat saja tenaga seseorang dibutuhkan walau sudah masanya usia pensiun/purnawirawan, melalui keputusan Presiden diperpanjang masa dinasnya. Orang tersebut bukan purnawirawan, tetapi militer penuh. Kekacauan yang timbul dalam hubungan pembahasan ini adalah seorang purnawirawan yang diangkat menjadi anggota DPR, lalu memperoleh dua kali hak politik. Pertama, demi hukum ikut serta memberikan suara dalam pemilihan umum karena sudah purnawirawan, dan kedua menjadi wakil ABRI di DPR. Penulis pernah menghadapi kasus pidana yang menyangkut purnawirawan. Karena purnawirawan dia ditolak diadili di Pengadilan Militer. Akhirnya dia diadili di Pengadilan Negeri/Sipil. Seharusnya seseorang yang sudah purnawirawan, ia kembali ke rakyat, menjadi anggota masyarakat biasa.

Lebih lanjut, perlu juga dibahas mengenai pegawai negeri dan korps pegawai negeri (Korpri) dalam hubungannya dengan sistem politik ketatanegaraan yang sedang berlaku selama orde baru. Tuntutannya dimulai dari setiap pegawai negeri otomatis masuk menjadi anggota Korpri, dari Korpri masuk anggota Golkar.

Selanjutnya menarik juga dibahas penjatahan di Golkar. Penjatahan yang berlaku di Golkar selama ini ada disebut 3 (tiga) jalur: Jalur A (ABRI), jalur B (Birokrat atau Korpri atau Pegawai Negeri), dan jalur G (Golkar). Melalui penjatahan tiga jalur ini,komponen Korpri mendapat jatah yang paling banyak dalam FKP 116 orang berasal dari Pegawai Negeri; 34 orang dari Pensiunan ABRI dan 96 orang dari swasta (jalur Golkar).

Penjelasan ini bertujuan untuk mencari alasan mengapa sejumlah anggota DPR sulit melaksanakan tugasnya secara optimum, khususnya tugas pengawasan. Mereka adalah anggota DPR yang berstatus pegawai negeri. Kesempatan mereka menjadi anggota DPR adalah karena status pegawai negeri, sehingga termasuk jalur B. Sebagai pegawai negeri (birokrat) nasib kepegawaiannya adalah tergantung di tangan Menteri. Setelah menjadi anggota DPR ia mempunyai tugas konstitusi mengawasi Presiden (termasuk Menteri). Sedangkan ia mendapat 
kesempatan menjadi anggota DPR adalah atas prakarsa atau restu atau izin atau kemurahan hari Menteri. ${ }^{50}$

Dapatlah dipahami bila banyak anggota DPR yang berasal dari birokrat penuh diplomasi menjalankan tugas-tugasnya. Penelitian keja sama DPR RI-FH UI menyimpulkan: ${ }^{51}$

\section{Anggota DPR yang mempunyai status seperti itu (ABRI dan pegawai negeri, pen), tidak dapat berbuat tidak sesuai dengan kebijaksanaan pemerintah, karena ada kekuatiran bila ia kembali kepada tugasnya nanti.}

Sedangkan menurut Soehardjo, ${ }^{52}$ kurang berfungsinya DPR dan sangat dominannya pemerintah yang dipimpin oleh Presiden, pertama, karena sistem rekruitmen para anggota Golongan Karya yang merupakan golongan yang dominan dalam DPR dan MPR. Rekruitmen dilakukan melalui penilaian yang ditentukan oleh tiga jalur yaitu jalur ABRI, jalur pemerintahan (Korpri), dan jalur pimpinan Golkar. Jadi, para anggota yang dicalonkan dan kemudian terpilih menjadi anggota MPR/DPR akan merasa berhutang budi kepada pimpinan tiga jalur. Kedua, setelah menjadi angota DPR, para anggota terikat oleh disiplin organisasi dan disiplin fraksi yang tinggi.

Selain DPR masih ada lembaga demokrasi lainnya yang melaksanakan tugas pengawasan yaitu pers dan pengadilan. ${ }^{53}$ Pers masuk ke dalam kelompok infrastruktur sedangkan peradilan/pengadilan masuk ke dalam kelompok suprastruktur politik, judikatif. Akan tetapi pengawasan yang dilakukan oleh pers, khususnya sejak tahun 1969 adalah pengawasan yang tidak berarti setelah pemerintah memperkenalkan konsep kebebasan pers yang bertanggungjawab ${ }^{54}$. Apalagi dengan keluarnya UU No. 12 Tahun 1982, melalui pasal 13 ayat (5) yang dilanjutkan dengan Peraturan Menteri Penerangan No. 1 Tahun 1982, membuat pers makin takut menjalankan fungsi pengawasan dengan ancaman pembatalan SIUPP. Adapun bunyi Pasal 13 ayat (5) adalah:

50 Penulis mempunyai beberapa orang teman anggota DPR berstatus pegawai negeri. Walaupun mereka anggota DPR, mereka takut sehingga kikuk bila berada di hadapan Menterinya. Ini adalah kenyataan dan yang wajar terjadi.

${ }^{51}$ Kerjasama DPR RI - FU UI, op. cit hal. 127

${ }^{52}$ Soehardjo, SS., Op. Cit., hal. 14.

${ }^{53}$ Dalam rumusan konferensi International Commission of Jurist 1965 di Bangkok, kedua ini adalah syarat negara demokrasi

54 Secara keseluruhan dapat dipahami keadaan control pers sejak tahun 1969 dengan membaca Tjipta Lesmana, 20 Tahun Kompas, "Profil Pers Indonesia Dewasa Ini" (Jakarta: Erwin Rika Press, 1985), hal. 125. 